\title{
A framework for assessing capacity in water governance
}

\author{
A. Zary ${ }^{1}, \mathrm{H}$. Bjornlund ${ }^{1,2}$ \& W. $\mathrm{Xu}^{1}$ \\ ${ }^{1}$ University of Lethbridge, Canada \\ ${ }^{2}$ University of South Australia, Australia
}

\begin{abstract}
Alberta's water governance is shaped by a complex web of provincial and federal acts and policies, inter-provincial, inter-territorial, and international management and allocation agreements, and local government bylaws. Adding to the intricacy, water governance is a collaborative process with government departments, government mandated agencies and non-governmental organizations involved. A diverse landscape and varying water needs also contribute to the complexity of water management. Recently, Alberta's water governance has evolved to become more of a collaborative bottom-up rather than top-down approach to management involving a wide range of stakeholders. The direction for water resource management has been driven primarily by the Water for Life strategy. With the shift from a top-down to a bottom-up approach to water management, many questions arise around the capacity of stakeholders to fulfill their roles in this governance structure. In this context, the paper develops a conceptual framework to assess stakeholder capacity in water governance which can be modified to be used in other geographic and resource contexts.
\end{abstract}

Keywords: water, water governance, capacity, capacity assessment frameworks, Alberta, Canada.

\section{Introduction}

Water governance in Alberta and elsewhere is shaped by a complex web of actors and is subject to formal and informal rules. Governance takes place at all scales, in diverse landscapes, and in conditions of varying levels of scarcity and demand pressures from many sectors of societies. Alberta's water governance structure has shifted from a top-down management approach to a collaborative management 
approach involving a wide range of stakeholders. A shift in governance requires an examination of the capacity of these stakeholders to carry out the tasks assigned to them and allow the governance system to adapt to the new management style. This paper develops a conceptual framework to assess stakeholder capacity in water governance.

The following section provides a definition of capacity and section three is an overview of capacity frameworks found in the literature. This is followed by a section on organizing the elements of capacity into capitals. On this basis we develop a conceptual framework which can be used to assess stakeholder capacity in water governance which can be modified to be used in other geographic and resource contexts.

\section{Defining capacity for water governance}

Capacity has been widely discussed within various disciplines since the 1990s [1-4]. Research in economics, health, education, information technologies (IT), community development, and climate change have paid considerable attention to capacity [3-6]. Within the water sector the initial focus was on capacity-building due to high levels of aid and development projects completed during the $60 \mathrm{~s}$ and 70 s that failed to deliver the promised outcomes [2]. These projects were focused on delivering the physical infrastructure with little thought to how the infrastructure would be managed and operated in the long term [1, 2]. Water practitioners were able to pinpoint the need to build human capacity as the reason for project failure and this concern led to two UNDP symposiums on water sector capacity-building in 1991 and 1996 to identify what capacity-building meant and what was needed to develop and implement capacity-building approaches and tools for aid and development projects [7].

Building on this, researchers realized that discussion on capacity-building could not actually take place without a discussion of capacity [2]. Capacity, simply put, is the capability of individuals, organizations and institutions to perform, manage, solve, accomplish, or withstand determined objectives or situations $[2,8]$. Capability has elements that exist and/or can be developed to create capacity $[2,8]$. Studies in areas of natural resource management and water and watershed management have shifted from capacity building to focus on understanding the elements of capability and how they work together to create capacity for the long term management of a system [1-3, 9-15]. In other words, the focus has shifted from project specific management to holistic management of water done at appropriate scale [1]. This shift involves a different set of capabilities and capacities from before.

\section{Defining the elements of capacity}

While there is a large body of literature on capacity spreading across several disciplines, there has been no universal theory or standardized method for measurement of capacity $[4,5]$. Nor is there even agreement on the elements of capability needed for capacity $[4,5]$. This is, in part, due to the multitude of 
elements that make up capability which determines capacity and the tendency of research to focus on specific elements or aspects of capacity [4, 5]. This section discusses the literature that identifies the key elements of a framework of capability.

The community and international development discipline was one of the first to make an effort to understand capacity. Chaskin [4] argues that capacity is a product made of different elements of a sense of community, commitment, ability to solve problems, and access to resources. Capacity is created first by engagement with social agency (the different social networks involved) to outline challenges and set strategies. Social agency is then applied to operationalize strategies through planning, access to resources, production of goods and services, and information dissemination. Capacity is adequate when desired outcomes are reached. Capacity requires a fluctuating level of capability, depending on the specific context, as stakeholders, social agency, and a variety of resources need to come together to accomplish a specific goal or task. The combination of stakeholders and level of social agency, and resources needed shift and change as new catalysts arise. While this framework provides some understanding of how various levels of capacity are needed in order to accomplish goals or solve problems, it does not identify many of the elements of capability that are needed to have capacity within any given context.

Still within community and international development disciplines, Beckley et al. [5] refine the conceptual model of capacity by pointing out that capacity is an outcome derived from a set of assets made up of natural, economic, human, and social capitals and are not put into motion without a trigger or event that requires capability. They agree with Chaskin [4] that: 1) capacity requires differing levels of capability in the natural, economic, human, and social depending on context; 2) communities as well as individuals have capitals, 3) social agency is required to access capitals, and 4) capacity is met when outcomes are achieved. However, they include a larger set of elements contributing to capability and group these elements of capabilities into capitals. They provide more insight into capability, its elements and their role in creating capacity.

A different perspective is offered by the resource management discipline. It sees the community (social agency) as the practitioners and stakeholders, who are already in place, and capacity as a set of measurable attributes that allow the community to function to a specific level $[6,14,16]$. Webb and Curtis [16] do not see capacity as a process where social agencies and resources converge; rather, it is made up of measurable capabilities which are a set of tangible and intangible 'things', or elements and are accessed by the practitioners as needed to accomplish goals. They too called these elements of capability capitals and acknowledge the need for elements from four different capitals - natural, produced economic (the harvested resources), human, and social. However they do not provide indicators for natural capital as they argue that it is the purpose of natural resource management.

Moore et al. [6] continue the process of developing a framework of capacity for natural resource management. Their framework continues to view capacity as a measure of elements. However, they add a new category that captures 
institutional arrangements and attributes, and argue that this is a separate realm from other types of capital. They also argue that natural capital is a key component of capacity that is measurable and critical to capacity within natural resource management. This difference of opinion between Webb and Curtis [16] and Moore et al. [6] on the importance of including natural capital in frameworks of capacity for management of natural resources is one that needs further research.

Within the water governance literature, de Loë et al. [11] developed one of the first water governance capacity frameworks that incorporate five capitals: technical, financial, social, political and institutional, each requiring many elements of capabilities. Other researchers, e.g. Moore et al. [6] and Robins [14], have argued that political and technical capacities are part of institutional capital rather than stand-alone capitals.

\section{Elements of capability as organized into capitals}

Outside of the above frameworks, the literature on the elements that make up capacity tends to focus on specific elements or capitals, and comprises the vast majority of papers on capacity. Natural capital is defined as the creation of economic and human wealth from nature such as mining, fibre production, fishing, oil and gas, etc., as well as the benefits provided by ecosystems such as nutrient cycling, flood abatement, water purification, etc. [5]. It also encompasses the actual aspects of nature such as wildlife, trees, air, water, etc. [5]. Table 1 shows the various elements of natural capital and the key literature that placed importance on each.

Table 1: Natural capital.

\begin{tabular}{lllll}
\hline \multicolumn{5}{c}{ Elements of capability } \\
\hline & $\begin{array}{l}\text { Ecosystem } \\
\text { services }\end{array}$ & $\begin{array}{l}\text { Extractable } \\
\text { natural } \\
\text { resources }\end{array}$ & $\begin{array}{l}\text { Jobs from } \\
\text { resource } \\
\text { extraction }\end{array}$ & $\begin{array}{l}\text { Appreciation of/ } \\
\text { access to nature }\end{array}$ \\
Key papers: & $\mathrm{X}$ & $\mathrm{X}$ & $\mathrm{X}$ & $\mathrm{X}$ \\
\hline Beckley et al. [5] & $\mathrm{X}$ & & & $\mathrm{X}$ \\
Bossel [17] & $\mathrm{X}$ & & $\mathrm{X}$ \\
Chiesura and de Groot [18] & $\mathrm{X}$ & & $\mathrm{X}$ \\
Olewiler [19] & $\mathrm{X}$ & $\mathrm{X}$ & \\
NRTEE [20] & $\mathrm{X}$ & $\mathrm{X}$ & & \\
Moore et al. [6] & & & & \\
\hline
\end{tabular}

Webb and Curtis [16], found that natural capital - as a stand-alone capital comprised of elements - was not significant to their respondents as they viewed natural capital as the reason for natural resource management, rather than a capacity. Moore et al. [6] argue that natural capital is not discussed in its own right. Instead its elements are discussed in the context of other capitals. In other disciplines, for example in the sustainability planning field, natural capital is considered to be the basis for evaluating environmental sustainability $[17,19,20]$ and the socio-cultural aspects of natural capital are viewed as integral to sustainability $[17,18]$. 
Economic capital is defined as the fixed and liquid elements, such as built infrastructure and various types of financial resources, that influence the capability of an individual, organization, business, institution or community to achieve goals $[5,6,11,14,16]$. There is little disagreement on the importance of economic capital although there is less agreement of what elements it constitutes of (Table 2).

Table 2: Economic capital.

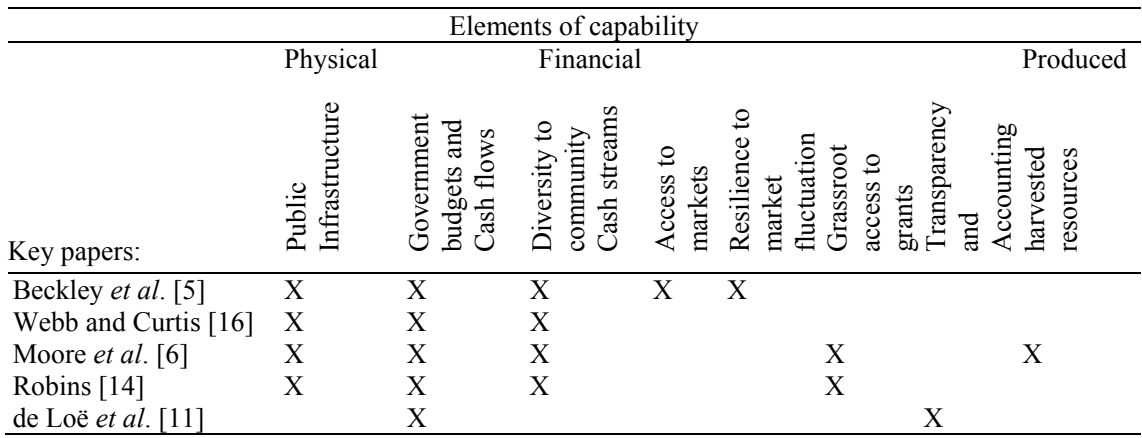

All key papers see government budgets and cash flows as important elements that make up the financial portion of economic capital. The addition of two other elements, diversity of community cash streams and public infrastructure, were included by four of the five papers. Moore et al. [6] and Robins [14] further adds that grassroot access to grants is critical, especially in light of the re-scaling of management decisions from top-down to bottom up approaches to resource governance. Moore et al. [6] include produced economic capacity. An example of this would be the cost incurred by citizens for their drinking water. Transparency and accountability were included by de Loë et al. [11] as important to ensure financial accountability as well as developing other mechanisms to keep accountability and transparency in institutions.

Human capital can be defined as the capabilities associated with personal resources and skills needed by an individual and accessed by organizations, institutions, businesses to achieve goals and objectives. It includes knowledge, skills, and experience [4-6, 20]. Table 3 shows various elements of human capital and the key literature that placed importance on them.

All key papers see education as a critical element of capability to human capital. Job experience, life experience and acquired skills, and indigenous and local knowledge are seen as critical in four of the six papers. Individual health is argued to give the social context and an overview of the community in order to understand its relationship with its environment $[5,16]$. In other words, healthy individuals are able to make better decisions and have more resilience [21]. Three key papers discuss leadership or the ability to produce champions. They argue that champions are important as they promote the importance of the work undertaken to all levels of society, build bridges between groups, and help facilitate important conversations that drive the impetus for change. Entrepreneurship, willingness to participate, and diversity are three elements mentioned in key papers once. 
Table 3: Human capital.

\begin{tabular}{|c|c|c|c|c|c|c|c|c|}
\hline \multirow[b]{2}{*}{ Key papers: } & \multicolumn{8}{|c|}{ Elements of capability } \\
\hline & 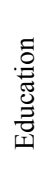 & 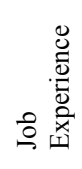 & 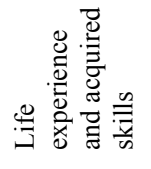 & 卺 & 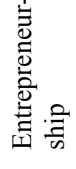 & 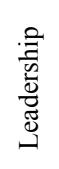 & 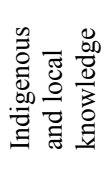 & 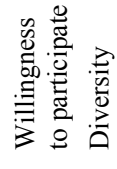 \\
\hline Chaskin [4] & $\mathrm{X}$ & & & & & & & $\mathrm{X}$ \\
\hline Beckley et al. [5] & $\mathrm{X}$ & $\mathrm{X}$ & $\mathrm{X}$ & $\mathrm{X}$ & $\mathrm{X}$ & $\mathrm{X}$ & $\mathrm{X}$ & \\
\hline Webb and Curtis [16] & $\mathrm{X}$ & & & $\mathrm{X}$ & & & & $\mathrm{X}$ \\
\hline NRTEE [20] & $\mathrm{X}$ & $\mathrm{X}$ & $\mathrm{X}$ & & & & $\mathrm{X}$ & \\
\hline Moore et al. [6] & $\mathrm{X}$ & $\mathrm{X}$ & $\mathrm{X}$ & & & & $\mathrm{X}$ & \\
\hline Robins [14] & $\mathrm{X}$ & $\mathrm{X}$ & $\mathrm{X}$ & & & & $\mathrm{X}$ & \\
\hline Davies [22] & & & & & & $\mathrm{X}$ & & \\
\hline Taylor [23] & & & & & & $\mathrm{X}$ & & \\
\hline
\end{tabular}

Social capital can be defined as the relationships between individuals, organizations, and institutions [4-6]. The capacity of these relationships can be measured through networks, levels of trust, reciprocity, commitment, motivation, as well as through values, attitudes and behaviours (Table 4) [4-6, 14].

Table 4: Social capital.

\begin{tabular}{|c|c|c|c|c|c|c|c|c|c|}
\hline \multicolumn{10}{|c|}{ Elements of capability: } \\
\hline Key papers: & 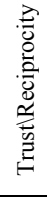 & 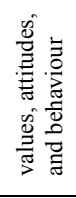 & $\begin{array}{l}\text { 泀 } \\
\text { 音 } \\
\text { 言 }\end{array}$ & 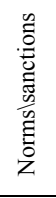 & 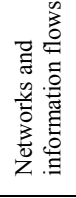 & 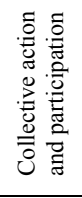 & 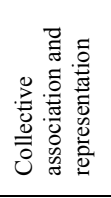 & 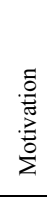 & 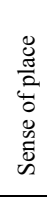 \\
\hline Chaskin [4] & & & & & $\mathrm{X}$ & & $\mathrm{X}$ & & \\
\hline Beckley et al. [5] & & & & $\mathrm{X}$ & $\mathrm{X}$ & $\mathrm{X}$ & & & \\
\hline Adger [24] & $\mathrm{X}$ & $\mathrm{X}$ & & $\mathrm{X}$ & $\mathrm{X}$ & $\mathrm{X}$ & & & \\
\hline Webb and Curtis [16] & & & & & & $\mathrm{X}$ & & & \\
\hline Moore et al. [6] & $\mathrm{X}$ & $\mathrm{X}$ & $\mathrm{X}$ & & $\mathrm{X}$ & & $\mathrm{X}$ & & $\mathrm{X}$ \\
\hline Robins [14] & $\mathrm{X}$ & $\mathrm{X}$ & $\mathrm{X}$ & & $\mathrm{X}$ & & $\mathrm{X}$ & $\mathrm{X}$ & $\mathrm{X}$ \\
\hline Pretty and Ward [25] & $\mathrm{X}$ & & & $\mathrm{X}$ & & & $\mathrm{X}$ & & \\
\hline Leach and Sabatier [26] & $\mathrm{X}$ & $\mathrm{X}$ & & & $\mathrm{X}$ & $\mathrm{X}$ & & & \\
\hline Pretty [27] & $\mathrm{X}$ & & & $\mathrm{X}$ & $\mathrm{X}$ & $\mathrm{X}$ & & & \\
\hline Floress et al. [28] & & & & & $\mathrm{X}$ & $\mathrm{X}$ & $\mathrm{X}$ & & \\
\hline de Loë et al. [11] & & & $\mathrm{X}$ & & $\mathrm{X}$ & $\mathrm{X}$ & $\mathrm{X}$ & & \\
\hline
\end{tabular}

Networking and information flows are seen as critical elements in nine out of eleven key papers. This is followed by collective action and participation, with seven key papers, and trust and reciprocity as well as collective association and representation with six key papers. Four key papers see values, attitudes and beliefs and norms and sanctions as critical to social capital. Elements of 
commitment, sense of place and motivation are mentioned in three key papers or less yet have a compelling argument for inclusion. For example, de Loë et al. [11] argue that municipal governments need commitment from the community - shown through various levels of public participation and engagement - in order to effectively develop and maintain programs and legislation that protect groundwater. Whereas Moore et al. [6] argue that commitment is more about agreement between practitioners to support each other in the decisions made and actions taken rather than having buy-in from the general public to implement the decisions made by a legislating body. Both Moore et al. [6] and Robins [14] argue that sense of place is important as those that see the uniqueness of their location and have feelings towards the landscape they reside in are more likely to engage in activities that promote and protect it than not [6].

Institutional capital is defined as the formal and informal rules - governance, legal structures, and social norms - that provide the context within which individuals, organizations, institutions, and society function (Table 5) [6, 14]. Beckley et al. [5] argue against the idea that institutional capital is separate from social capital as they run on similar principals as society and require the same elements of capability. However, others argue for a separate capital for institutional processes and that there are unique elements that show capacity in institutions. All but one key paper argue that the main element found in institutional capital is rules and incentives. These are the legal, regulatory, and policy tools that provide the rules and incentives for the institution to do the required work and it is applicable at any scale. Other elements are not as universally agreed upon. These elements range from technical tools to management practices to organizational relationships.

Table 5: Institutional capital.

\begin{tabular}{|c|c|c|c|c|c|c|c|c|c|}
\hline \multicolumn{10}{|c|}{ Elements of capability } \\
\hline Key papers: & 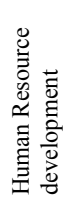 & 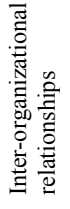 & 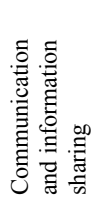 & 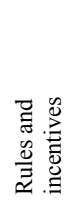 & 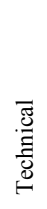 & 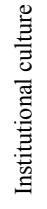 & 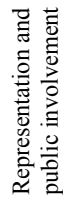 & 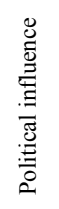 & 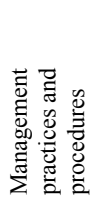 \\
\hline Chaskin [4] & & $\mathrm{X}$ & & & & & $\mathrm{X}$ & $\mathrm{X}$ & \\
\hline Brown [29] & $\mathrm{X}$ & $\mathrm{X}$ & $\mathrm{X}$ & $\mathrm{X}$ & & $\mathrm{X}$ & & & $\mathrm{X}$ \\
\hline Cosío [30] & & & & $\mathrm{X}$ & $\mathrm{X}$ & & & & \\
\hline de Loë et al. [11] & & $\mathrm{X}$ & $\mathrm{X}$ & $\mathrm{X}$ & $\mathrm{X}$ & & & & $\mathrm{X}$ \\
\hline Ivey et al. [12] & & & & $\mathrm{X}$ & $\mathrm{X}$ & & $\mathrm{X}$ & & \\
\hline Moore et al. [6] & & & & $\mathrm{X}$ & & & & & \\
\hline Robins [14] & & & & $\mathrm{X}$ & & & & & \\
\hline Van de Meene et al. [31] & $\mathrm{X}$ & & $\mathrm{X}$ & $\mathrm{X}$ & $\mathrm{X}$ & & $\mathrm{X}$ & & $\mathrm{X}$ \\
\hline
\end{tabular}




\section{Assessing capacity and building a framework}

Qualitative and mixed method assessments are the most common approaches to assessing capacity in the literature. Often these papers develop indicators based on the literature and then assess using in-depth or structured interviews, analysis of documents, compilation of policies, procedures, and practices, etc. For example, de Loë et al. [11] analysed the capacity of local governments in Ontario to protect groundwater. They developed indicators from the literature for five sub-categories of institutional capital - financial, technical, social, institutional, and political. The capacity was then analysed using a variety of methods including in-depth interviews and analysis of municipal documents, consultant reports, and other numerous documents. Some indicators were devised as checklists. For example, a list of specific policies and processes was developed, and then documentation was checked to see if the municipality had those as part of their governance structure. Some, like the ones for financial capacity, were based on absolute numbers and source of income.

While quantitative assessments are not as common, however, they too use the literature to develop indicators for each type of capital. For example, in one study on community capacity for watershed conservation, researchers developed a list of social indicators of capacity based on the literature and then measured using a seven point Likert scale in a survey [32]. Principal components analysis was conducted to reduce the number of indicators to reflect key factors of capacity. These factors were collective action, community empowerment, and shared vision. They found that collective action and community empowerment predicted the most variability in overall capacity.

There are three core concepts that emerge from the literature on water governance and capacity: i) capacity is fluid $[1,2,10,33]$; ii) the level of capacity is determined by its capitals [11-13, 26, 32, 34, 35]; and iii) each of the capitals are made up of a variety of elements of capabilities [4-6, 11, 14, 16]. What currently is missing from the literature is an overarching and comprehensive discussion of which elements of capability should be included in each capital and whether each of those elements and capitals have relevance to water governance.

Combining the capitals discussed in section 4 and their elements of capabilities we developed a framework of capacity (Table 6). As discussed, there is disagreement about the importance of natural capital; however, we decided to include it in this framework because resource endowment is very much geographically contingent. Each of the other capitals has all of the elements discussed in the key papers. This allows for established elements such as rules and incentives found in institutional capital as well as for new elements such as diversity found in human capital to be examined in a closer manner. This framework can then be analysed using the results of a research design developed to capture the perspectives of stakeholders in water governance. By investigating what is most important to the stakeholders actually involved in water governance processes, it will be possible to determine which elements of capabilities are relevant to water governance. 
Table 6: Proposed elements of capabilities in the capitals.

\begin{tabular}{|c|c|c|c|c|}
\hline Natural capital & Economic capital & Human capital & Social capital & institutional capital \\
\hline $\begin{array}{l}\text { Ecosystem } \\
\text { services }\end{array}$ & $\begin{array}{l}\text { Public } \\
\text { infrastructure }\end{array}$ & Education & $\begin{array}{l}\text { Trust and } \\
\text { reciprocity }\end{array}$ & $\begin{array}{l}\text { Human resources } \\
\text { development }\end{array}$ \\
\hline $\begin{array}{l}\text { Extractable } \\
\text { natural resources }\end{array}$ & $\begin{array}{l}\text { Government } \\
\text { budget and cash } \\
\text { flows }\end{array}$ & Job experience & $\begin{array}{l}\text { Values, attitudes, } \\
\text { and behaviors }\end{array}$ & $\begin{array}{l}\text { Inter-organizational } \\
\text { relationships }\end{array}$ \\
\hline $\begin{array}{l}\text { Income/jobs } \\
\text { from resource } \\
\text { extraction }\end{array}$ & $\begin{array}{l}\text { Diversity to } \\
\text { community cash } \\
\text { streams }\end{array}$ & $\begin{array}{l}\text { Life experience and } \\
\text { acquired skills }\end{array}$ & Commitment & $\begin{array}{l}\text { Communication and } \\
\text { information sharing }\end{array}$ \\
\hline \multirow{6}{*}{$\begin{array}{l}\text { Appreciation } \\
\text { of/access to } \\
\text { nature }\end{array}$} & Access to markets & individual Health & $\begin{array}{l}\text { Norms and } \\
\text { sanctions }\end{array}$ & Rules and incentives \\
\hline & $\begin{array}{l}\text { Resilience to } \\
\text { market fluctuation }\end{array}$ & Entrepreneurship & $\begin{array}{l}\text { Networks and } \\
\text { information flows }\end{array}$ & Technical \\
\hline & $\begin{array}{l}\text { Grassroots access } \\
\text { to grants }\end{array}$ & Leadership & $\begin{array}{l}\text { Collective action } \\
\text { and participation }\end{array}$ & Institutional culture \\
\hline & $\begin{array}{l}\text { Transparency and } \\
\text { accounting }\end{array}$ & $\begin{array}{l}\text { Indigenous and local } \\
\text { knowledge }\end{array}$ & $\begin{array}{l}\text { Collective } \\
\text { representation } \\
\text { and association }\end{array}$ & $\begin{array}{l}\text { Representation and } \\
\text { public involvement }\end{array}$ \\
\hline & $\begin{array}{l}\text { Harvested } \\
\text { resources }\end{array}$ & $\begin{array}{l}\text { Willingness to } \\
\text { participate }\end{array}$ & Motivation & Political influence \\
\hline & & Diversity & Sense of place & $\begin{array}{l}\text { Management } \\
\text { practices and } \\
\text { procedures }\end{array}$ \\
\hline
\end{tabular}

\section{Conclusion}

The basic definitions of capacity and capability as well as the broad grouping of elements of capability into capitals have, over a period of time, coalesced $[4,5,13]$. Whether all of the elements of capability have been identified and whether they are all equally important to water governance are not clear as the required level of each capability needed for sufficient capacity is fluid and depend on the context, the objective to be met, type of organization, project, person, or institution, and the point in time $[5,13,14]$. The proposed framework collects the elements identified in the literature into one location. This allows policy makers and water managers engaged in water governance processes to first test to see if all these elements are indeed important to water governance in their specific context, then to devise a system of measuring the capacity of the governance system to see if it seems to be adequate to the task and if not identify areas where further capacity building is needed. Given the critical importance of governance in contemporary water planning and management this is of critical importance for policy makers for successful outcomes. Early experiences both from Alberta in Canada and from Australia suggest that lack of stakeholder capacity in water planning processes has been a key contributor to prolonged and often conflict ridden planning processes with contested outcomes. 


\section{Acknowledgements}

The authors would like to acknowledge the financial contribution from Alberta Innovates: Energy and Environment Solution, the Canadian Social Sciences and Humanities Research Council's Water Economics, Policy and Governance Network, and from Prairie Water News.

\section{References}

[1] Alaerts, G.J., F.J.A. Hartvelt, and J.F. Warner, Capacity building - beyond the 'project' approach. Waterlines, 1997. 15(4): pp. 2-5.

[2] Franks, T., Capacity building and institutional development: Reflections on water. Public Administration and Development, 1999. 19: pp. 51-61.

[3] Ivey, J.L., J. Smithers, R.C. de Löe, and R.D. Kreutzwiser, Community capacity for adaptation to climate-induced water shortages: Linking institutional complexity and local actors. Environmental Management, 2004. 33(1): pp. 36-47.

[4] Chaskin, R.J., Building community capacity: A definitional framework and case studies from a comprehensive community initiative. Urban Affairs Review, 2001. 36(3): pp. 291-323.

[5] Beckley, T.M., D. Martz, S. Nadeau, E. Wall, and B. Reimer, Multiple capacities, multiple outcomes: Delving deeper into the meaning of community capacity. Journal of Rural and Community Development, 2008. 3(3): pp. 56-75.

[6] Moore, S.A., R.C. Severn, and R. Millar, A conceptual model of community capacity for biodiversity conservation outcomes. Geographical Research, 2006. 44(4): pp. 361-371.

[7] Abrams, L., Capacity building for water supply and sanitation development at the local level: The threshold concept, in Water sector capacity building: Concepts and instruments: Proceedings of the second UNDP symposium on water sector capacity building Delft, 1996, G.J. Alaerts, F.J.A. Hartvelt, and F.M. Patorni, Editors. 1999, A.A. Balkema: Rotterdam, Netherlands. pp. 301-310.

[8] Teohareva, M., What is capacity building? Journal of Environmental Protection and Ecology, 2011. 12(4): pp. 1804-1807.

[9] Armitage, D., Adaptive capacity and community-based natural resource management. Environmental Management, 2005. 35(6): pp. 703-15.

[10] Arreguin, F., L. Marquez, and A. Gomez, Capacity building in Mexico. Water Resources Development, 1996. 12(4): pp. 483-490.

[11] de Loë, R.C., S.E. Di Giantomasso, and R.D. Kreutzwiser, Local capacity for groundwater protection in Ontario. Environmental Management, 2002. 29(2): pp. 217-233.

[12] Ivey, J.L., R. de Loë, R. Kreutzwiser, and C. Ferreyra, An institutional perspective on local capacity for source water protection. Geoforum, 2006. 37(6): pp. 944-957. 
[13] Pres, A., Capacity building: A possible approach to improved water resources management. International Journal of Water Resources Development, 2008. 24(1): pp. 123-129.

[14] Robins, L., Making capacity building meaningful: A framework for strategic action. Environmental Management, 2008. 42(5): pp. 833-46.

[15] Robins, L., Capacity building for natural resource management: Lessons from risk and emergency management. Australasian Journal of Environmental Management, 2008. 15: pp. 6-20.

[16] Webb, T.J. and A. Curtis, Mapping regional capacity for natural resources management, in People, practice and policy: A review of social and institutional research. 2006, Land \& Water Australia, Australian Government: Canberra, Australia. pp. 51-54.

[17] Bossel, H., Indicators for sustainable development: Theory, method, applications. 1999, International Institute for Sustainable Development: Winnipeg, MB. p. 123.

[18] Chiesura, A. and R. de Groot, Critical natural capital: A socio-cultural perspective. Ecological Economics, 2003. 44(2/3): pp. 219-231.

[19] Olewiler, N., Environmental sustainability for urban areas: The role of natural capital indicators. Cities, 2006. 23(3): pp. 184-195.

[20] NRTEE, The state of the debate on the environment and the economy: Environment and sustainable development indicators for Canada. 2003, National Round Table on the Environment and the Economy: Ottawa, ON. p. 92.

[21] Webb, T.J., K. Cody, B. Harrison, A. Sincock, and C. Mues, Social and economic information for NRM: An initial discussion paper, December 2004. 2004, National Land \& Water Resources Audit: Canberra, ACT. p. 27.

[22] Davies, A., Understanding local leadership in building the capacity of rural communities in Australia. Geographical Research, 2009. 47(4): pp. 380389.

[23] Taylor, A.C., Building leadership capacity to drive sustainable water management: the evaluation of a customised program. Water science and technology: a journal of the International Association on Water Pollution Research, 2010. 61(11): pp. 2797-807.

[24] Adger, W.N., Social capital, collective action, and adaptation to climate change. Economic Geography, 2003. 79(4): pp. 287-404.

[25] Pretty, J. and H. Ward, Social capital and the environment. World Development, 2001. 29(2): pp. 209-227.

[26] Leach, W.D. and P.A. Sabatier, Are trust and social capital the keys to success?: Watershed partnerships in California and Washington, in Swimming Upstream: Collaborative Approaches to Watershed Management, P.A. Sabatier, et al., Editors. 2005, Massachusetts Institute of Technology: Cambridge, MA. pp. 233-258.

[27] Pretty, J., Social capital and the collective management of resources. Science, 2003. 302(5652): pp. 1912-1914. 
[28] Floress, K., L.S. Prokopy, and S.B. Allred, It's who you know: Social capital, social networks, and watershed groups. Society \& Natural Resources, 2011. 24(9): pp. 871-886.

[29] Brown, R.R., Local institutional development and organizational change for advancing sustainable urban water futures. Environmental Management, 2008. 41(2): pp. 221-233.

[30] Cosío, R.G.G.á., Social constructivism and capacity building for environmental governance. International Planning Studies, 1998. 3(3): pp. 367-389.

[31] Van de Meene, S.J., R.R. Brown, and M.A. Farrelly, Exploring sustainable urban water governance: A case study of institutional capacity. Water Science \& Technology, 2009. 59(10): pp. 1921-1928.

[32] Brinkman, E., E. Seekamp, M.A. Davenport, and J.M. Brehm, Community capacity for watershed conservation: A quantitative assessment of indicators and core dimensions. Environmental Management, 2012. 50(4): pp. 736-749.

[33] Alaerts, G.J., F.J.A. Hartvelt, and F.M. Patorni, eds. Water sector capacity building: Concepts and instruments: Proceedings of the second UNDP symposium on water sector capacity building, Delft, 1996. 1999, A.A. Balkema: Rotterdam. 455.

[34] de Loë, R.C. and D.K. Lukovich, Groundwater protection on Long Island, New York: A study in management capacity. Journal of Environmental Planning and Management, 2004. 47(4): pp. 517-539.

[35] Ivey, J.L., R.C. De Loë, and R.D. Kreutzwiser, Groundwater management by watershed agencies: An evaluation of the capacity of Ontario's conservation authorities. Journal of Environmental Management, 2002. 64(3): pp. 311-331. 